TANULMÁNYOK 2019/1. Bölcsészettudományi Kar, Újvidék

STUDIJE 2019/1. Filozofski fakultet, Novi Sad

STUDIES 2019/1. Faculty of Philosophy, Novi Sad

ETO: 7.071.1(38)(091)

ORIGINAL SCIENTIFIC PAPER

37.013 .43

DOI: $10.19090 / \mathrm{tm} .2019 .1 .101-122$

A kézirat leadásának időpontja: 2019. szeptember 22.

Az elfogadás időpontja: 2019. szeptember 27.

\author{
TÁMBA Renátó \\ Reménysugár Habilitációs Intézet \\ Budapest, Magyarország \\ trenato87@gmail.com
}

\title{
GYERMEKJELENETEK A HELLENISZTIKUS GÖRÖG SZOBRÁSZATBAN
}

\section{Predstavljanje dece u helenističkoj grčkoj skulpturi}

\section{Representations of Children in the Hellenistic Greek Sculpture}

Jelen írásban a hellenisztikus görög szobrászat gyermekéletképeinek áttekintésére vállalkozom, azzal a szándékkal, hogy a gyermekkortörténeti ikonográfia módszertani eszközeivel rámutassak az alkotások mögött húzódó, a kor formálódóban lévő emberképét kifejező eszme- és társadalomtörténeti motívumokra, valamint a müveken tetten érhető specifikus gyermekszemléleti mintázatokra. Vizsgálataim során eszme-, társadalom-, művészet- és gyermekkortörténeti szempontokat egyformán figyelembe vettem, így mindenekelőtt szükségesnek látszott kijelölni az elemzések tárgyunk szempontjából mérvadó történeti kereteit. Vizsgálatom célja, hogy átfogó képet nyújtsak a kor szobrászatának gyermekábrázolásairól, egyúttal rávilágítva az alkotásokból kiolvasható ikonográfiai és ikonológiai jelentésekre, a művek mögött húzódó eszmei jelentéstartalmakra, kulturális utalásokra is, miután e művek a gyermekkor témáján túlmutatva reflektálnak az egzisztenciális kérdések irányába nyitott kor érzékeny, végső soron az etikai relativizmus ösvényén haladó kérdésfelvetéseire is.

Kulcsszavak: hellenizmus, gyermekszemlélet, individualista-naturalista ábrázolás, spinario, ephebos

\section{Bevezetés}

A klasszikus poliszdemokrácia megszűnésével és a hellenisztikus birodalmak létrejöttével gyökeresen megváltozott a hellénség emberképe. Míg a klasszikus kor embereszménye garanciát jelentett egyén és közösség organikus kapcsolatára, addig a koiné földjén az individuum etikai tájékozódásában megszüntek 
az egyértelmű orientációs pontok. Megkérdőjeleződött az egyén társadalomban betöltött szerepe, így előtérbe került az individuum problémája. Ebben az ember természeti valója, élethelyzeteinek realitása felé nyitott korban válhatott lehetővé a gyermekábrázolások elszaporodása, hiszen a közfelfogás szerint a gyermekkor maga is számottevően természeti meghatározottságú volt.

Írásomban - egy átfogó munka részeként - e korszak szobrászatának gyermekéletképeit tekintem át, az alkotások mögött megbúvó eszmetörténeti motívumok, gyermekszemléleti mintázatok feltárása céljából. Feltevésem szerint a tárgyalt alkotások rendre az általános szellemi bizonytalanság által kiváltott egzisztenciális útkeresés kérdésfelvetéseit hordozzák magukban, azokra reflektálnak, gyakran az ember természeti és ösztönvalójának kíméletlen feltárásával, olykor némi iróniával, illetve ironikus kulturális utalással elegyítve. Munkámban tehát arra is keresem a választ, hogy miféle képet közvetítenek e művek a kor emberszemléletével kapcsolatban és milyen kompozíciós eszközök révén. További kérdésként merül fel, hogy mi áll a gyermekábrázolások megnövekedett számának, illetve a gyermeki vonások megjelenésének hátterében, s e kérdés felé a megváltozott világnézeti tartalmak, esztétikai felfogások, formanyelvi jellemzők, valamint gyermekszemléleti mintázatok felől közelíthetünk. Elemzéseim során a gyermekkortörténeti ikonográfia általam kidolgozott módszerét alkalmazom (Támba 2017, 79-122; lásd még Endrődy-Nagy 2015, 35-100).

\section{Az individualizmus irányába ható léttartalmak a hellenizmus társadalmában és kultúrájában}

Az athéniak makedónbarát szónoka, Isokratés már Kr. e. 380 k. megfogalmazta, hogy a „hellén” megnevezés immár lelkialkatot és müveltségtípust jelöl, nem pedig vérrokonságot, tehát hellénnek tekinthető mindenki, aki átvette a görög kultúra hagyományait (Hegyi et al. 2002, 260). E felfogás már előkészítette a hellenizmus szemléletmódját, melynek meghatározó vonása Droysen szerint sem más, mint a hellén müveltségnek a nem görög etnikumokra történő átvitele (Hegyi et al. 2002, 261). E felfogás nyomán kibontakozott az egyetemes görögség eszméje az első világegység koncepciójának jegyében (Hegyi et al. 2002, 262), összhangban a hellénség egységes államszervezetbe tömörülésének arisztotelészi elképzelésével (Hegyi et al. 2002, 311).

Éppen Arisztotelész volt a nevelője annak a makedón államférfinak, Nagy Sándornak, akinek apja, II. Philipposz Kr. e. 338-ban, a khairóneiai csatában megverte a görögöket, kivezetve őket a hellénség anarchikus állapotából (Castiglione 1996, 15). Nagy Sándor apjának a pánhellén szünmakhia kialakítá- 
sára vonatkozó tervén (Zamarovsky 1980, 276) is túltéve kívánta megvalósítani a tanítója által említett államszervezet elképzelését, immár ökumenikus méretben, Isokratés szellemében kiterjesztve a hellénség határait egészen a Közép-Keletig. Kiemelte a kölcsönös kulturális hatás fontosságát (Hegyi et al. 2002, 312), s megfogalmazta annak kívánalmát, hogy az embert többé ne származása, hanem müveltsége alapján különböztessék meg (Bengtson 2009, 54), ezzel lerakva egy új korszak szemléletének alapjait. A hellenizmus kora azonban csak az uralkodó halálával (Kr. e. 323) kezdődött meg (Bengtson 2009, 7), hogy az ipszoszi csatát követően diadokhoszai a meghódított oikumenét felosztva létrehozzák a hellenisztikus birodalmakat (Castiglione 1968, 208; Castiglione 1996, 17).

Nagy Sándor államéletről szóló elképzelései nyomán tovább éltek ugyan a klasszikus görög polisz önkormányzati intézményei, ám a város immár alárendelődött az állami hatalomnak (Hegyi et al. 2002, 314). A poliszdemokrácia korszaka letűnt, s ahogyan a politikai irányítás feladata a poliszok kezéből a központi hataloméba került, úgy csúszott ki a közvélemény és a cselekvés befolyásolásának ereje a görög ember kezéből, aki többé már nem poliszpolgár volt, hanem az uralkodói parancsok engedelmes végrehajtója (Castiglione 1996, 21). A poliszállamok polgárai korábban szorosan kötődtek városuk közösségéhez, az élet lényegét pedig nem másban látták, mint a szűk hazához kötődő politikai létben (Németh 2004, 18), ám a poliszrendszer felbomlásával az egyén társadalomhoz való viszonya teljességében megkérdőjeleződött (Hoffmann 2009, 62). Így társadalmi érdeklődése beszűkült, s fokozatosan megszűnt a közösségi és a magánélet azonosságának eszméje is (Castiglione 1996, 21).

Az individuum mindinkább elidegenedett a societastól (Castiglione 1996, 7), s miután a hellenisztikus monarchiákat már nem tudta hazájának tekinteni (Hoffmann 2009, 62), érdeklődése az egyéni élet problémái felé fordult (Castiglione 1996, 22). Képlékennyé vált a hitrendszer (Bengtson 2009, 149), átértékelődtek a klasszikus erkölcsök a kalokagathia eszméjével együtt. Megkérdőjeleződött az igaz és a jó mibenléte (Hauser 1968, 74), a jóindulat, a szelídség és az emberbaráti gondolkodás értékének előtérbe kerülése pedig egyértelmüen jelezte az individuum problémái iránti érzékenységet.

Az új szellemi áramlatok az egyéni úton történő boldogulásban vélték megtalálni a boldogságnak mint az élet végcéljának a kulcsát (Castiglione 1968, 219). Epikurosz elutasította „az isteni világkormányzás eszméjét” (Long-Sedley 2014, 155), s ennek nyomán a boldogság forrását a gyönyör elérésében vélte felfedezni (Long-Sedley 2014, 155), a lélek zavartalan állapotának elérése céljából (Falus, 2005) pedig a közösségi élettől visszavonult életmódot hirdette (Bengtson 2009, 58). Vele szemben a sztoikusok minduntalan hangsúlyozták a természettel össze- 
hangolt, az erkölcsi jóság által vezérelt élet kívánalmát (Long-Sedley 2014, 484), valamint az emberszeretet fogalmát, az isteni gondviselés tanából (Long-Sedley 2014, 561) és a logosz elvéből kiindulva vallva az egész világra kiterjedő testvérség eszméjét (Bengtson 2009, 55; Swiderkowna 1981, 11). Ezzel szemben a cinikusok törekvése a polgári értékek és a vagyon jelentőségének tagadásában ragadható meg a társadalomban való függetlenség elérésére törekedve (Zamarovsky 1980, 312), a pürrhónizmus pedig ismeretelméleti alapot nyújtott az etikai és esztétikai értékítélettől való tartózkodás gyakorlata számára (Zamarovsky 1980, 311; Long-Sedley 2014, 30). Egymás után formálódtak ki tehát a klasszikus értékeket megkérdőjelező szellemi áramlatok, melyek érzékenyen reflektáltak a kor emberének létélményére. E reflexiók a képzőmüvészeti ábrázolás szemléletmódjára is hamar átterjedtek, így aztán a kornak az individuum problémájára vonatkozó kérdésfelvetései a műalkotásokból is kiolvashatók.

\section{Az eszmei-társadalmi tartalom és a formanyelv változásai a hellenisztikus szobrászatban}

A hellén világ kitágulásával az egyén mindinkább eltávolodott társadalmi környezetétől, ezért aztán visszavonult belső világába (Falus 2005). A poliszpolgár identitástudatának megrendülése nyomán kiveszett a müvészetből a tökéletes állampolgárról szóló felfogás (Castiglione 1968, 167), s az ókori Hellász szellemi egységét tükröző szemlélet helyett a művészek mindinkább az individuális lét felé fordultak (Castiglione 1968, 189), ahogyan azt az irodalomban Leónidasz epigrammáiban vagy Theokritosz idilljeiben is tapasztalhatjuk (Fox 1996, 372, 374, 381). A pheidiaszi plasztika önmagában nyugvó belső egyensúlyával, klasszikus zártságával (Castiglione 1996, 61-62), a poliszdemokrácia rendíthetetlen eszmei egységét tükröző nemes egyszerüségével szemben (Hauser 1968, 79) az új vizuális nyelv mind oldottabbá és szenvedélyesebbé vált, gyakran némi melankóliától terhelten (Castiglione 1996, 61-62). Az individualista-naturalista, szubjektív-emocionális jellegü ábrázolásmód irányába történő változás (Hauser 1968, 73, 81) gyökerei a késő klasszikus szobrászatra vezethetők vissza, hiszen a pergamoni és a rhodoszi iskola nagyrészt Szkopaszból táplálkozott, akinek kicsavarodott testü, fájdalmas arckifejezéssel ábrázolt, mozgalmas-patetikus nőalakjai (Sarti 2007, 37) „az élet küzdelmét” (Castiglione 1968, 191) hivatottak kifejezni, Praxitelész támasztékot kereső, kiegyensúlyozatlan figurái (Castiglione 1968, 173) pedig az alexandriai realizmus idillikus életképeire és női aktjaira gyakoroltak nagy befolyást. E szobrászok munkái már a Hellász világnézeti megrendülését fejezték ki szeszélyes, dinamikus ábrázolásmódjukkal, ám a hellenisztikus szobrászat számára a leglényegibb hatás Nagy Sándor udvari szobrásza, a 
sziküóni-argoszi iskola képviselöje, Lüszipposz felöl érkezett (Castiglione 1996, 19). Lüszipposz leghíresebb kijelentése szerint ő az embert nem olyannak kívánja ábrázolni, amilyen, hanem olyannak, amilyennek látszik. Ez nem mást takar, mint hogy Lüszipposz eltávolodott az ember „tiszta eszméjéből”, lényegi vonásaiból kiinduló alkotásmódtól, s mindinkább közeledett egy, az érzéki benyomásokból táplálkozó, az ember természeti valóságáról közvetlen képet nyújtó ábrázolásmód felé (Castiglione 1968, 211). Ez a koncepció a platóni ideatan értelmében a „látszat” kategóriájába esett az „igaz” művészi megformálásával szemben, hiszen az embert esetlegességénél és érző-szenvedő mivoltánál fogva kívánta bemutatni. Míg a heroizmustól és arisztokratikus szigortól meghatározott (Hauser 1968, 74), a klasszikus embereszmény nyomán az „igaz” kategóriáját müködtető, klasszikus görög szobrászat az alakot kiemelte az időből, hogy áthelyezze egyfajta állandósággal és időtlenséggel bíró, a köznapi léttől, a platóni értelemben vett „látszatvalóságtól” messze járó állapotba, addig Lüszipposz visszahozta az embert a köznapi, vagyis a pillanatokban való létezés közegébe. Így kerülhetett előtérbe az egyszeriség élménye az ember megismételhetetlen voltának felismerésével együtt (Hauser 1968, 74).

Lüszipposz Apoxüomenosz című alkotása immár nem a győztes atléta klaszszikus ideálját nyújtja, hanem a versenytől megfáradt férfi érzékeny zsánerjelenetét. $\mathrm{E}$ mủ esetében a pszichológiai közvetlenség és esetlegesség érzetének - a testtartás és az arckifejezés rögzítésén túl (Castiglione 1968,200) - a térbenyúlás gesztusa ad igazán érvényt (Castiglione 1968, 193), hiszen ennek révén a mü meghódítja a tér mindhárom dimenzióját (Castiglione 1996, 61-62), ezzel mintegy leszámolva a klasszikus szobrászatra jellemző egynézetü ábrázolásmóddal, mely korábban lehetővé tette a klasszikus embereszményről alkotott egységes képet zavaró vonások kirekesztését (Castiglione 1968, 219). A hellenisztikus szobrászatot innentől - egészen a II. századig - a többnézetűség határozta meg, amelynek értelmében a szobor által nyújtott kép egésze csak annak körbejárása nyomán válik felfoghatóvá. Ezzel a test kilépett a klasszikus görög plasztika állandóságélményétől meghatározott ideális térből a pillanatnyiság és az esetlegesség terébe, s ezt a fordulatot az átmeneti, állás és lépés között lévő mozgásállapot csak hangsúlyosabbá tette (Castiglione 1996, 61-62), ahogyan a kicsavarodott testtartás és a drapéria redői által keltett fény-árnyék hatás is ezen és más alkotásokon (Boardman 2007, 230).

Az esetlegesség érzetének irányába hat itt a lüszipposzi kánon is, melynek következtében a polükleitoszi arányrendszerhez képest a fej kisebbé, a végtagok hosszabbakká, karcsúbbakká és inasabbakká váltak, s ezzel a művész egy újabb lépést tett az érzékelhető valóság leképezése felé. Hiszen míg a klasszikus kor szobrászai a fej arányaiban történő megnagyításával kívánták jelezni az értelem 
uralkodó szerepét (Castiglione 1968, 197), addig az új korszak művésze a természetes arányok használatával immár visszahelyezte figuráját a maga természeti valójába. Az új, közvetlen benyomásokon alapuló ábrázolás szemléletmódját támogatta meg a kor művészetszemléletét átható arisztotelészi miméziselmélet (Castiglione 1968, 200), s általában a kor Arisztotelésztől eredeztethető természettudományos felfogása is (Castiglione 1968, 204).

A lüszipposzi alapozás korszakát követően, a formálódás szakaszának dinamizmusát - a belső hatalmi harcok következtében (Castiglione 1996, 64) - a Kr. e. III. század elejének egyszerű, zárt koncentrációra törekvő stílusa szakította meg (Castiglione 1996, 65), melynek iskolapéldája Polüektosz Démoszthenészszobra (Kr. e. 280 k.). Ezt követően a Kr. e. III. század szigorúan egyszerü, határozottan összefogott kompozíciói már visszatértek a természet esetleges jelenségeinek bemutatásához (Castiglione 1996, 66). Csak a század második felében vált jellemzővé a bonyolult testhelyzetek megjelenítése, különös figyelemmel „a saját tengelye körül megcsavarodó test ábrázolására” (Castiglione 1996, 67), gondolva itt például az Ülő leányra (Castiglione 1996, 73).

A hellenisztikus birodalmak fenyegetettségének súlyosbodásával a Kr. e. III-II. század fordulóján szónokias lendület lett úrrá a művészeten, melynek iskolapéldája a Gall hadvezér és feleségének csoportja (Castiglione 1996, 75), mely a fény-árnyék kontraszt és a felfokozott drámaiság okán (Sarti 2007,279) már a pergamoni barokkhoz sorolható (Castiglione 1996, 75). E stílus verisztikus áramlata gyakorta hajlott a nyomor, az öregség és a szenvedés bemutatására (Castiglione 1968, 241); ennek iskolapéldája a gall csoportot idéző gúlás kompozícióba foglalt Részeg öregasszony (Mürón alkotása) (Castiglione 1968, 241), mely az ábrázolt lelkiállapotának megragadása okán Lüszipposz örökségének továbbviteléről tanúskodik (Sarti 2007, 273). Hasonlóan realisztikus alkotás az Öreg halász, mely a groteszk vonások ábrázolásával immár az alexandriai realizmus szobrászatát dicséri (Sarti 2007, 278), mely irányzat javarészt Praxitelész felfogásából táplálkozott (Auboyer et al. 1986, 168).

Ugyanakkor az új müvészeti irányzatok könnyüszerrel magukba fogadták nemcsak a szenvedés és a test elhasználódásának problémakörét, de a gyermekkor témáját is. Miután az ógörög gondolkodásban a gyermekkor maga is elsősorban természeti meghatározottságánál fogva definiált életszakasz volt, így magától értetődő, hogy e korban nyerhetett polgárjogot a számottevően örömaspektusainál fogva definiált kora gyermekkor ábrázolása a szépmüvészetekben. Ezek az ábrázolások - különösen az írásomban vizsgált zsánerjelenetek - egyfelől reflektálnak az individuális lét pszichés-morális problémáira, másrészt pedig szemléletesen tükrözik a kor gyermekszemléletét. 


\section{Gyermekszemlélet a klasszikus és a hellenisztikus görög társadalomban}

Az ókori görögök roppant nagy értéket tulajdonítottak a gyermekkornak, hiszen a jövőhöz való kapcsolódás zálogának tekintették (French 1998, 49). Számos irodalmi leírás tanúskodik a kisded anatómiai és lélektani sajátosságainak, a gyermeki természet sajátosságainak megfigyeléséröl, gyakran számot adva a gyermek testi gyengeségéröl vallott felfogásukról, ahogyan azt Pindarosz ódájában is láthatjuk. A végtagok formálhatóságára vonatkozó felismerésüket pedig párhuzamba vonták a személyiség, a karakter alakíthatóságára vonatkozó elképzeléseikkel, többek között ezzel igazolták azon felfogásukat, mi szerint a gyermek testi és értelmi aspektusból egyformán nevelhető, a gyermek tehát tanítást igényel (French 1998, 51). Bár a gyermeket többnyire fegyelmezett, önuralomra képes lénynek tartották (French 1998, 52), a gyermek kialakulatlanságáról szóló elképzeléshez kapcsolódóan a kisdedet erkölcsileg befolyásolhatónak, hiszékenynek és tudatlannak vélték. Ugyanakkor számos alkalommal jelenik meg az irodalomban ártatlan, szeretetre méltó, vidám teremtésként (French 1998, 51), a csecsemő dédelgetéséről szóló leírások pedig tanúsítják a gyermekhez fordulás mozzanatát, mely a hellenizmus korában vált még hangsúlyosabbá. Ugyanis Plutarkhosz például már felhívta az anyák figyelmét a szoptatás jelentőségére a szeretetteljes kapcsolat formálódása szempontjából, az apákat pedig kevésbé szigorú bánásmódra intette (Pukánszky 2004, 39; French, 1998, 53-54; Fináczy 1922, 184).

Az ókori görög nevelési rendszerben az engedelmesség (French 1998, 52), a fegyelmezettség és az önuralom rendkívül fontos nevelési értékeknek számítottak, mégpedig a kalokagathia eszményének elérése érdekében, melynek meghatározó motívuma a testi szépség és az erkölcsi fejlettség (a jóság) egységének elve volt. A kalokagathia csakis a derekasság (areté) erénye révén fejlődhet ki az egyénben, mely pedig a komplex múzsai (irodalmi, művészeti) és gümnasztikai (testi, fizikai) nevelés révén valósulhat meg (Pukánszky 2004, 42; Fináczy 1922, 80). Ennek rendszereként fejlődött ki a klasszikus görög művelődés rendszerét jelentő paideia (Németh 2004, 18), mely a gyermek pszichés-morális karaktere fejlődésének kulturális bázisát nyújtotta. Ez a hellenizmus korában még hangsúlyosabbá vált, hiszen ebben a korban már többé nem a vérségi kötelék jelentette a hellén identitás (a „görögnek lenni”) zálogát, hanem a görög müveltség (nyelv, irodalom, retorikai képzettség) elsajátítása (Hoffmann 2009, 63). Már Isokratés is hangsúlyozta, hogy immár nem állhat az egész társadalom a magas fokú hellén müveltség birtokában, csak az válhat igazán hellénné, aki erőfeszítéseket tesz a komplex műveltség elsajátítására (Hoffmann 2009, 63), melynek 
meghatározó eleme felfogása szerint a retorika volt (Hoffmann 2009, 64). Hellén műveltségre elvileg bárki szert tehetett, de a társadalmi rétegződésből fakadóan (lásd Pukánszky 2004, 43) valójában csak kevesen érhették el a megkívánt magas szintet, melynek megszerzését a gymnasion és az ephebia biztosította (Hoffmann 2009, 63, 64).

A görög nevelés felfogását követve később Plutarkhosz is roppant jelentőséget tulajdonított az értelem kiművelését célzó kitartó gyakorlásnak és szorgalomnak az erkölcsi fejlődés és a jellemformálódás szempontjából, kiemelt figyelmet szentelve az irodalmi alkotások tanulmányozásának (Hoffmann 2009, 74). Ám ő már felhívta a figyelmet a pihenés jelentőségére is, óva intett tehát a növendékek túlterhelésétől (Hoffmann 2009, 74). Ezzel ő már voltaképpen előtérbe hozta az individuum problémáját (Hoffmann 2009, 74; Fináczy 1922, 186), s nagy hangsúlyt fektetett a családi kapcsolatok jelentőségére, a kölcsönös tiszteletre, valamint a szülők nevelői felelősségére is (Fináczy 1922, 188). Plutarkhosz szemléletének megfogalmazásával egyúttal mintegy retrospektív látleletet adott a hellenizmus átformálódott gyermek- és nevelésfelfogásáról, mely a gyermekábrázolások tanulmányozása során is roppant szembeötlő.

\section{Gyermekéletképek a hellenisztikus szobrászatban}

A gyermekek megjelenítésének az ógörög művészetben a késő klasszikus korig - Képhisodotos Eiréné a gyermek Plútosszal (Kr. e. 370 k.) és az ő fiának, Praxitelésznek Hermész a gyermek Dionüszosszal (Kr. e. 330 k.) címü márványkompozíciójáig - nem volt számottevő hagyománya. Amforákon, freskókon találkozunk ugyan játszó, illetve testi fenyítés alatt álló gyermekekkel, de ezeken gyermekietlen arányokkal, mintegy „miniatürizált felnőttként” kerültek ábrázolásra a kicsik. A gyermekábrázolások a hellenizmus korában kerültek igazán elötérbe, s ekkor vált jellemzővé a gyermeki vonások megjelenítése is, ám ehhez a szobrászatot átható alapvető eszmei tartalom, s ennek nyomán az általános pszichikai beállítottság kellett hogy megváltozzon (lásd Tatarkiewicz 2006). Ahogyan a poliszdemokrácia elsorvadásával az irodalomban a Szophoklésznál és Aiszkhülosznál még érvényes egyetemes igazságosságba és fátumba vetett hitet az esetlegesség és véletlenszerüség mozzanata váltotta fel (Hauser 1968, 75), úgy vette át a szobrászatban a kalokagathia eszméjét magában hordó idealizált atléta- és héroszábrázolás harmónián és klasszikus kontraposzton nyugvó ábrázolásmódjának helyét egy szenvedélyes, mozgalmas vizuális nyelv. Az új megjelenítésmód pedig a klasszikus görög embereszmény képlékennyé válását tükrözte, az ezzel együtt megjelenő új társadalmi érzékenységgel együtt. 
A poliszdemokrácia megszűnésének, $s$ azzal együtt az egyénnek a közösségtől való elidegenedésének következtében egzisztenciális válság bontakozott ki, melynek következtében jellemzővé vált a legkülönfélébb társadalmi csoportok, élethelyzetek, lelkiállapotok és életkorok megfigyelése (lásd Tatarkiewicz 2006). E korban élte virágkorát a gyermekábrázolás is, hiszen e korszakban bomlott le az a klasszikus emberideál, melyet az örök érvényü erkölcsi tartalmak bizonyossága táplált, s ennélfogva eszmei gátját jelentette a lényegében - az e korban - a pillanatnyiságánál, befejezetlenségénél, esetlenségénél, gyámoltalanságánál fogva jellemzett gyermekkor (lásd French 1998, 51-52) ábrázolásának. Tehát az etikai relativizmusnak a szofistáknál már tapasztalható, ám a hellenizmus korában elmélyülő gyakorlata kellett ahhoz, hogy az emberléptékű gondolkodásmód nyomán (lásd Hauser 1968,74) végre polgárjogra emelkedjen a gyermekábrázolás.

A nagy ideálok és bizonyosságok hanyatlásával tehát a figyelem a tünékenység és az érzékiség felé fordult, felértékelődtek az élet közvetlenül érzékelhető aspektusai, ahogyan a gyermekkor témája is a képzőművészetben. A gyermekfelfogás maga pedig életszerübbé, közvetlenebbé vált, $s$ ahelyett, hogy az eszmék felől közelítették volna meg a gyermeket, mind nagyobb figyelmet szenteltek a gyermeki természet megfigyelésének, a magánéletben és a müalkotásokon egyaránt.

Az átalakuló gyermekszemlélet és az áttételes kulturális utalások a gyermekéletképeken jelentkeznek a leghangsúlyosabban. A hellenisztikus gyermekzsáner egyik legismertebb példája a müncheni Glyptothekben őrzött, $84 \mathrm{~cm}$ magas Libával birkózó kisfiú címü kompozíciós, mely eredetileg bronzszobor volt, de pentelikoni márványból készült római másolat formájában maradt az utókorra. A vélhetően kis-ázsiai görög szobrász munkáján a liba feje modern kiegészítés (Castiglione 1968, 284). A mü stílusjegyei arra utalnak, hogy az eredeti munka a Kr. e. III. század második felében készülhetett; a fej Kr. e. IV. századi előképeket idéz. Plinius Historia Naturalae címú munkájában a khalkedóni Boethost azonosítja mestereként, ám Castiglione szerint az ő alkotása kacsát fojtogató gyermeket ábrázolt. A zsánerjelenet egy kisfiú és egy liba ádáz küzdelmét mutatja be, amint a kisfiú megpróbálja legyürni a libát. Miután a Kr. e. III. században élt költő, Hérondasz egy hasonló művet említ Aszklépeion fogadalmi ajándékai között, elképzelhető, hogy e jelenet eredetileg azt kívánta bemutatni, amint a kisfiú az üdvére felajánlott áldozati állatot igyekszik megölni (Castiglione 1968, 285).

\footnotetext{
${ }^{53}$ A kép forráshelye: Castiglione 1968, 232.
} 


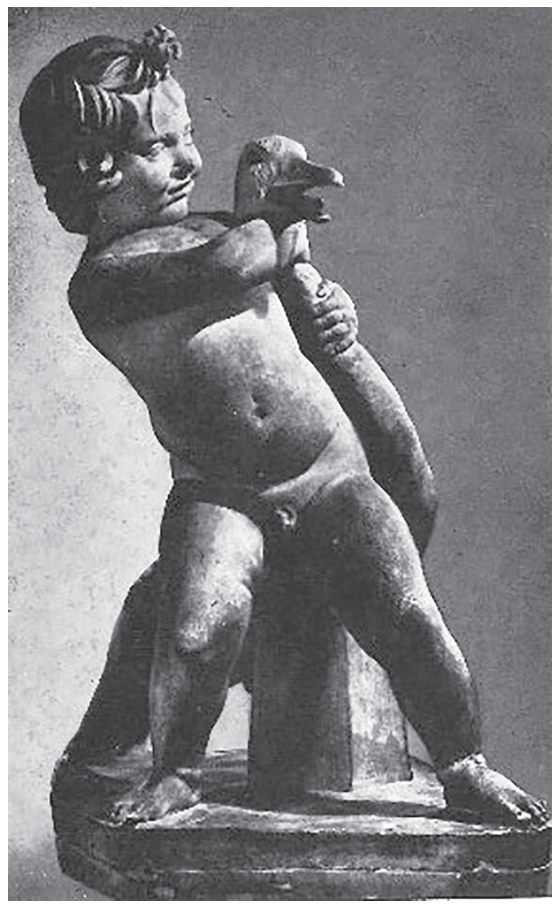

Mindenesetre a gyermek és a szárnyas küzdelmének ábrázolása e korban gyakori volt. E bájos párviadal mintha csak a korábbi századok népszerü atlétikai viadalainak paródiáját kívánná nyújtani (Auboyer et al. 1986, 164), e korban ugyanis már csak ironikus felhanggal gondolhattak az emberek az egykor dicsöséges sportra. A kétalakos csoport piramidális, spirálisan körkörös kompozíciója által úgy csúcsosodik ki a két figura küzdelme, akárcsak a hősi tragédiák nagy, pátosztól dagadó jeleneteiben, amelyekben élet vagy halál a tét (Castiglione 1968, 226), gondolva itt mindenekelött a Gall hadvezér és feleségének csoportját bemutató alkotásra (Kr. e. III. század vége). A pergamoni szobrászat realisztikus alkotása spirális szerkesztésmódja okán nemes, férfias pátoszt hordoz magában (Castiglione 1968, 224), ezzel szemben a libás fiú csoportjából legfeljebb az ezen hősies pátosz fölötti derüs irónia olvasható ki. Hiszen itt nem mondai vagy mitológiai hősök vívják a harcot, hanem „a baromfiudvar hőse” és a fejletlen, párnás testü, bájosan esetlen, éppen hogy járni képes „pufók kisgyerek” (Castiglione 1968, 226). Tehát azáltal, hogy e teljességgel hétköznapi zsánerjelenet a gall csoporthoz és más heroikus csoportokhoz hasonló kompozíciót kapott, e müben szóhoz jut egyfajta ironikus kételkedés a hősi tettek értelme fölött, ezzel együtt hirdetve az individuum mikrouniverzumba való visszavonulásának epikureus eszméjét (lásd Bengtson 2009, 58). 
Mindezen túl e mü a kor azon gyermekábrázolásainak sorába illeszthető, melyek azon túl, hogy nagyfokú anatómiai ismeretről tanúskodnak, különös kreativitásra és érzékenységre vall a csontok és izomzatok plasztikus megformálása terén is. Ezt mutatja a gyermek hurkás lábain megfeszülő izmok és jóllakott, kerek pocakján a köldök ábrázolása, illetve a kitartó erőlködés feszült, gúlás kompozícióban történő megjelenítése is (Castiglione 1996, 86). A gyerekkori erőpróbát ábrázoló bukolikus hangú, már-már Theokritosz idilljeinek hangulatát idéző zsánerjelenet elevenségével, közvetlenségével hat, a gyermekkort pedig bájosságánál, esetlenségénél, inkompetenciájánál fogva mutatja be, s egyúttal képes kifejezni a felnőtt társadalomnak a gyermekkor bája iránti érzékenységét (French 1998, 51).

A hétköznapi életből meríti témáját a British Museumban örzött, Spinario (Tövishúzó fiú) ${ }^{54}$ néven jegyzett, eredetileg a Kr. e. III. században készült, de ma már csak a Kr. e. II. századból való, római kori márványmásolatáról ismert szobor is (magassága $69 \mathrm{~cm}$, szélessége 40,5 cm, mélysége $35 \mathrm{~cm}$ ). A mü egy kövön ülő, talpából egy tüskét eltávolítani igyekvő fiút ábrázol; jobb lába erőteljesen hiányos. A sziklán fúrt lyukak egykor egy szökőkút csöveinek adtak helyet (The British Museum é. n. a).

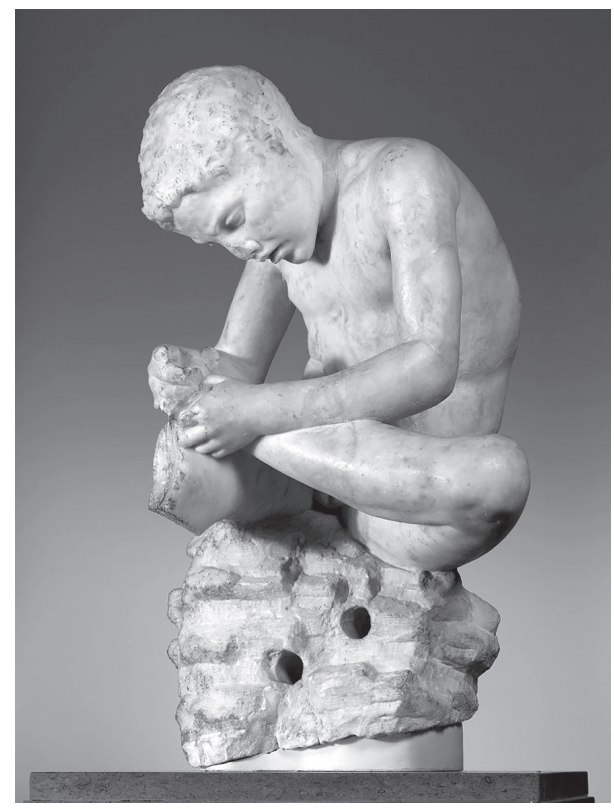

\footnotetext{
${ }^{54}$ A kép forráshelye: The British Museum. https://www.britishmuseum.org/research/collection_online/ collection_object_details.aspx?objectId=460414\&partId=1\&object=20170\&sortBy=imageName\&pa ge $=1$ (2019. jún. 11.)
} 
A mủ egy futóverseny utáni jelenetet ábrázol: a megfáradt versenyző leül, hogy kiszedje a versenyzés közben talpába fúródott tüskét; a hellenisztikus szobrászat köréből számos ehhez hasonló jelenetet ismerünk (Auboyer et al. 1986, 159). A témából fakadóan a gyermek testi fájdalma kerül előtérbe a győzelem diadalával vagy a versenyzés lendületével szemben, eltávolodva a klasszikus kor atlétaábrázolásainak nemes pátoszától, vagy épp Polükleitosz Dárdavivőjének (Kr. e. 440 k.) „igazságot is felülmúló bájától” (Quintilianust idézi Panofsky 1998, 15) egy individualista-naturalista jellegü ábrázolásmód (Hauser 1968, 73) érdekében. A klasszikus embereszmény méltóságteljes voltával való leszámolást jelzi a végtagok szerteágazó elhelyezése (az egymásra vetett lábak, a talphoz rögzített karok) is a klasszikus szobrászat kontraposzt-tartásával, kiegyensúlyozottságot és harmóniát árasztó mozgáshelyzeteivel szemben.

Az alkotás - témájával és kompozíciójával - tükrözi a hellenisztikus birodalmak egyensúlyvesztett állapotát, $s$ érzékelhetővé teszi azt az eszmetörténeti fordulatot, melynek értelmében a közösségi identitás helyére az individuum problémája került. A klasszikus poliszdemokrácia közösségeszményének eltünésével megszűnt a nagy erőfeszítések mögött húzódó közösségi motiváció, így az ember önnön belső világa felé fordul (Falus 2005), jobban elmélyülve saját testi-lelki fájdalmaiban (Castiglione 1968, 189). A kalokagathia eszményének való megfelelni vágyás nyomában járó összpontosítást itt a szobor háttértörténetét képező futás mozzanata jelenti, a gyötrelmekkel való foglalatoskodást pedig a tüske motívuma teszi érzékelhetővé. E képlet szerint a futás mintegy a múlt klasszikus, közösségi eszményének szimbólumává válik, míg a tövishúzás lesz az egzisztenciális válságtól terhelt jelen létélményének, s egyúttal az individuum problémái felé való fordulás kifejezőjévé.

A Spinarión az izmok és inak anatómiailag hủ kidolgozása, a lüszipposzi kánon nyomában járó nyúlánk testalkat ábrázolása egyaránt a naturalisztikus jelleg irányába hat. A tövishúzás műveletére való fókuszálást kifejező, s egyúttal zárt, befelé építkező kompozíciót eredményező görnyedt tartás és a feszült tekintet, valamint a szintén a koncentrálást kifejező félig nyitott száj nyomán érzékelhetővé válik a fiú belefeledkezése saját fájdalmába, s ezáltal az az érzésünk támad, mintha csak saját testének börtönébe volna zárva. A klasszikus szobrászat elöretekintő atlétáival szemben e fiú tekintete immár nem a befogadóra, hanem saját gyötrelmének tárgyára irányul, kifejezve a fájdalomtól való megszabadulás törekvését, amely mögött már-már az epikureus bölcselet hatása sejthetö, mi szerint a boldogság elérésének feltétele a fájdalom kiküszöbölése vagy leküzdése (Zamarovsky 1980, 309). E figura ahelyett, hogy a klasszikus poliszdemokrácia közösségi embereszményét tükrözné, immár a közösségi élettől elvonult, önnön 
problémájára fókuszáló individuum újfajta felfogását hordozza magában, s ez az új emberszemlélet mintha már valóban Epikurosz hatásáról tanúskodna (vö. Bengtson 2009, 58).

E mű tehát egy szűkösnek ható, a külvilágot kizáró individuális mikrouniverzumot jelenít meg, melyben a testi aspektus messze túlnő a lelki-szellemi dimenzión. Ráadásul az anatómiai jegyek tekintetében is távol áll ez az ábrázolás a klasszikus atlétaeszménytöl, hiszen például Kritiosz-kurosz (vagy Kritioszephebosz [Kr. e. 480 k., 86 cm magas]) egyenes testü, büszke tartású, egészséges testfelépítésű győztes ifjú alakjával szemben (lásd Boardman 2007, 132) itt egy magába görnyedt, satnya végtagokkal bíró, vézna, fejletlen fiúcskát látunk, aki még a serdülőkor éveit tapossa, a frontális beállítás nyitottsága helyett pedig mintegy introvertált melankólia lesz rajta úrrá.

A spinario-típus másik híres példája a firenzei Uffizi Galéria által őrzött Tövishúzó fiứ5, mely Lüszipposz hatását mutatja, többek közt az üres térrel való játék, valamint a gyermek előző ábrázoláshoz képest nyúlánkabb testalkata

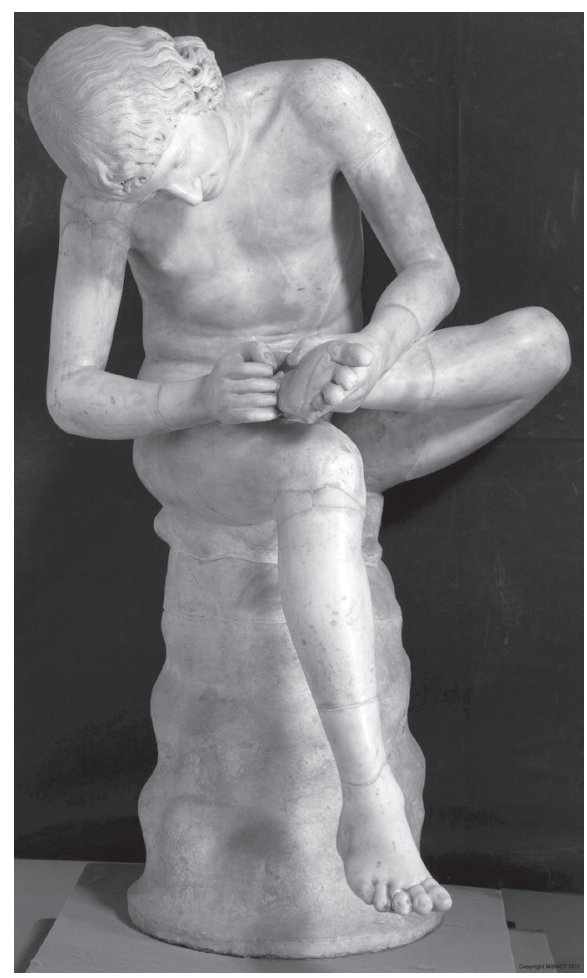

\footnotetext{
${ }^{55}$ A kép forráshelye: Le Gallerie degli Uffizi. https://www.uffizi.it/en/artworks/lo-spinario-or-boy-withthorn (2019. aug. 24.)
} 
okán (Auboyer et al. 1986, 167). A szobor eredetileg a Kr. e. III. századból való, de a múzeumban őrzött, $84 \mathrm{~cm}$ magas változata a Kr. e. I. század végén készült, márványból. Egyik bronzváltozatát a modern időkben először a Kr. u. 12. században találták meg Rómában, de elképzelhetö, hogy valójában ez az eredeti mű.

A mű háttértörténete szerint itt is futóverseny utáni jelenetet látunk. A naturalisztikusan kidolgozott, sürü csigákba rendezett hajviselettel ábrázolt fiú figurájánál itt sem a győzelmen, hanem a fájdalmon van a hangsúly, illetve az attól való megszabadulás törekvésén, amely - a görnyedt testtartás okán - itt is zárt, befelé irányuló kompozíciót eredményez. E mü melankolikus töprengés a hősi tettek, nagy erőfeszítések értelme fölött, de az előző mühöz hasonló hedonista példázat is kiolvasható belőle, melynek tanulságaképpen balgaság a testi erők mindennemű túlzó összpontosítása (Zamarovsky 1980, 309).

Mint láthattuk, voltaképpen az előző jelenetek mindegyike magában hordoz egyfajta, a heroikus erőfeszítések fölött kétkedő magatartást, jelezve a klasszikus embereszmény régóta idejétmúlt voltát. Nincs ez másképp az Artemiszion-fok előtti tengerszakaszban, 1926-ban talált, gyermek lovast ábrázoló bronzszoborral sem, mely immár közvetlenül sportjelenetet ábrázol. Az Artemiszion-foki gyermek lovas bronzszobra a Kr. e. II. századból való (Sarti 2007, 276) ${ }^{56}$, feltehetö-

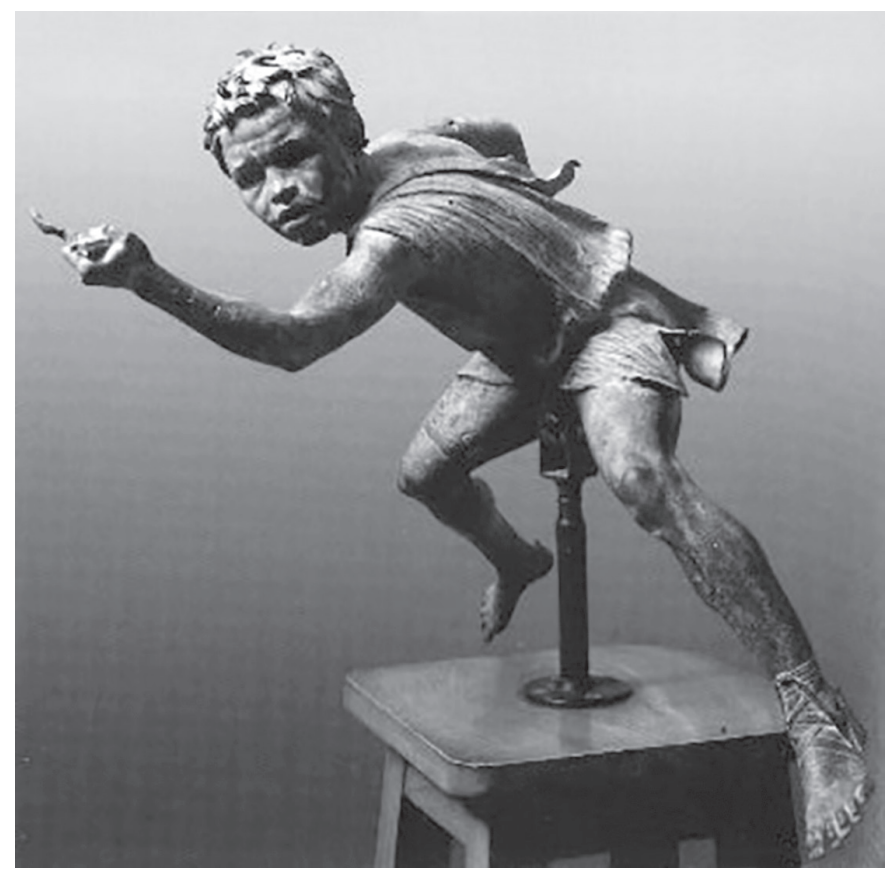

${ }^{56}$ A kép forráshelye: Sarti 2007, 276. 
en Kr. e. 150-146 között készült, s egy elsüllyedt hajó rakományából került elö egy szigorú kori müvel együtt (Castiglione 1996, 90). A szobron látható dedikálás alapján feltételezhetjük, hogy a mü egy vagyonos ember isteneknek szánt áldozati ajándékaként készülhetett. A művet ma az Athéni Nemzeti Régészeti Múzeum őrzi.

A gyermek testének arányai már Lüszipposz stílusára jellemzőek, ahogyan a portrészerünek tetsző, aprólékosan kidolgozott gyermeki arc is, de a ló alakja a maga merev nyaktartásával és hosszú, keskeny fejformájával még a klasszikus kor modelljeit idézi (Sarti 2007, 276). Ugyanakkor „a klasszikus müvészet méltóságteljes és kiegyensúlyozottan ritmikus lélegzésével szemben" e mü a pillanatnyiság, az esetlegesség jegyeinél (Castiglione 1996, 91) fogva jellemzett természeti való mimetikus rögzítésének szándékával készült, tehát itt már nem egy eszme tükröztetése, hanem a természeti való nyomán keletkezett benyomás, a lüszipposzi (vagy épp platóni) értelemben vett „látszat” visszaadása a cél (Castiglione 1968, 211). A pillanatszerüség kompozíciós eszközei közül ezen az alkotáson szembeötlő a mű zaklatott felülete, mozgalmassága, dinamizmusa, a „túlhajtottan” heves mozgás, valamint „a tér minden irányába sugárzó centrifugalitás" (Castiglione 1996, 91). A kompozíciót jellemző centrifugális szerkesztés lényege a szoborkompozíció irányából való kitekintés, a szerteágazó mozdulatok megjelenítése, ebből fakadóan pedig a többnézetűség és a körbejárhatóság. Mindebből fakadóan pedig az alkotást egyfajta naturalisztikusan szenvedélyes expresszivitás járja át (Castiglione 1996, 92).

Az ikonográfiai hagyományokat követve a fiatal lovas szőrén üli meg a lábait kinyújtó állatot, amelynek minden tagja az izmokat, ereket és inakat átható feszültséget teszi érzékelhetővé. Ló és lovasa szélsebesen, lendületesen vágtáznak a cél felé, a gyorsaságot jelzi a ló hátracsapott füle, de a levegőbe mintegy belehasító feje is. A fiú láthatóan a ló véknyába vájja sarkantyúját, így ösztönözve őt nagyobb sebességre; eközben bal kezével meglazítja a gyeplöt, leengedett jobb kezével pedig hátranyúl ostoráért. A gyermek kócos hajtincsekkel borított feje balra fordul, jelezve, hogy a célba érés elötti pillanatokban az ellenséget keresi tekintetével. A fiú viseletéül szolgáló övvel megkötött gyapjú khitón „valósággal lobog a sebes vágta keltette szélben" (Sarti 2007, 277).

A lovaglás a klasszikus görög nevelés rendszerében előkelő helyet foglalt el az ifjak által gyakorolt sportok között, s egyúttal ez volt az egyik legfontosabb eleme a nyilvános versenyeknek. A Parthenón frízének lovagló epheboszokat ábrázoló klasszikus részleteivel összehasonlítva feltünő, hogy az artemiszioni lovas alakja már messze van a klasszikus görög lovas ideáljától, hiszen e fiú sovány testével, vékony tagjaival inkább már zsokénak hat, a győzelemre irányuló erőfeszítés okán pedig arca mintegy eltorzul, csapzott hajzata és lihegést mutató 
szája a verseny hevét, pillanatszerüségét jelzi. Így a szélsebes vágta lendületében lovával szinte eggyé vált gyermek lovas alakjából kivész mindaz, ami még az örök érvényünek tekintett értékeket hordozó klasszikus görög szépségeszményt jellemezte (Castiglione 1996, 91). Az idealizált férfitestben összpontosuló klaszszikus embereszmény helyébe itt a mozgás esetlegessége kerül, az örök értékek harmóniája helyébe pedig a véghetetlen mozgás véletlenszerüsége (Castiglione 1996, 92). Ezen az alapon állítható szembe a delphoi fogathajtó bronzszobrának (Kr. e. 478 vagy 474; $180 \mathrm{~cm}$ magas) frontalitásával és szertartásos merevségével (lásd Boardman 2007, 141) a gyermek lovas szeszélyes ábrázolásmódja.

Ahhoz hasonlóan, ahogyan azt Lüszipposz évszázadokkal korábban megfogalmazta, az artemiszioni gyermek lovas szobrásza a fiút olyannak ábrázolta, amilyennek a valóságban látszott a maga érzéki aspektusainál fogva, s nem pedig az alakjához kapcsolható eszmei tartalmak tükrében (Castiglione 1968, 211). E figura - kicsavarodott testtartásánál, körbejárhatóságánál, drapériájának bőséges redőinél és az egész alak mozgalmasságánál fogva (Boardman 2007, 230) - immár a pillanatokban való létezés közegében mozog, messze jár már a „tiszta eszmék” ideális világától. Ezáltal pedig előtérbe kerülnek itt a gyermekkor anatómiai, fiziognómiai és pszichés aspektusai (Castiglione 1968, 200), mint amilyen például a fiú csapzott haja és messzeségbe révedő tekintete. Alkotásunkon a gyermek élethüen, egy serdülő arányaival jelent meg, immár magában hordozva a hellenizmus arisztotelészi alapú természettudományos szemléletmódjának tanulságait (Castiglione 1968, 200, 204). A kalokagathia eszményétől való eltávolodást hordozó stílusjegyek ennél már csak a capitoliumi Ökölvívó bronzszobrán (Kr. e. III. sz., 1,28 m, Róma, Museo Nazionale Romano) szembetűnőbbek (lásd Siebler 2008, 90).

Ugyancsak a serdülö lét naturalisztikus ábrázolását nyújtja Diphilos Tegezt hordó fiúgyermek címü $24 \mathrm{~cm}$ magas terrakottafigurája ${ }^{57}$, mely már a hellenizmus legvégén készült, Myrinában, a kis-ázsiai Minorban, ma pedig a British Museum örzi. A mű egy hattyú- vagy lúdfej formát öltő markolatgombbal díszített, nyíllal teli tegezt hordozó, rövid, göndör hajjal, nagy és hangsúlyos szemhéjakkal ábrázolt fiúgyermeket mutat. Ruházatát illetően egy vállán átvetett, vállánál egy levél alakú csattal rögzített, földig érő himationban került ábrázolásra, jobb kezét jobb oldalához tartva, bal kezét mellkasához fogva. A szobor barna agyagból, fehér mészből készült, a fiú himationján rózsamész figyelhető meg, a bőrön pedig narancssárga festékmaradvány. A mü hátán Diphilos szignatúrája látható (The British Museum é. n. b).

\footnotetext{
${ }^{57}$ A kép forráshelye: The British Museum. https://www.britishmuseum.org/research/collection_online/ collection_object_details.aspx?assetId=363208001\&objectId=460450\&partId=1 (2019. jún. 11.)
} 


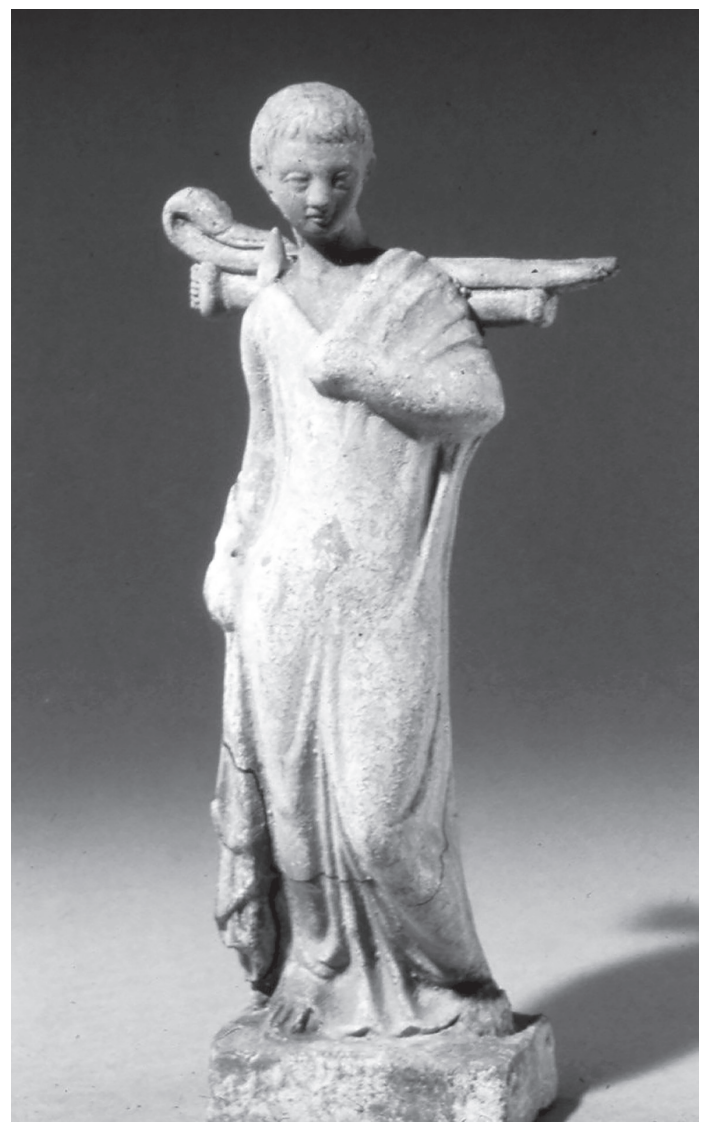

A tegezhordozó fiú lépő mozdulatban került ábrázolásra, oldalra biccentett fejjel; mozgásának és tekintetének iránya egymással ellentétes, mintha csak egy figyelmét elvonó eseményt kémlelne. A fejnek a test tengelyétől való kitérése fokozza a mű elevenségét, pillanatszerüségét, érzékeltetve a gyermekkor valóságát. A fiú alakja a lüszipposzi arányok szerint került megszerkesztésre, így figurája nyúlánk, amit egybefüggő ruházata csak hangsúlyosabbá tesz. A ruha felületén kevés a ránc, ám a két láb között a mozgás hatására keletkező redők hangsúlyosak, fény-árnyék hatást eredményeznek, kiemelik a mozgás aktusát.

Testének nagy része takarásban van, ám lába mezítelen, ezzel érzékeltetve szegénységét, természetközeli életmódját, és így hangsúlyozva a vándorlás tényét. A gyermek arcvonásai nagyobb, serdülőkorú fiút sejtetnek, tekintete kissé fásult, a mindennapi élet szüsziphoszi ritmusába való beletagolódást, beletörődést érzékelteti. A mü a hellenizmus bukolikus költészetének hangulatát és tematikáját idézi, gondolva itt például Theokritosz költeményeinek atmoszférájára. 
Szintén a hellenisztikus szobrászat aprólékosan kidolgozott, naturalisztikus gyermekábrázolásai közé tartozik a budapesti Szépművészeti Múzeum által őrzött Kisfiú asztragalosszal címü 101,8 cm magas márványszobor ${ }^{58}$, annak ellenére, hogy e mű már a Kr. e. I. század utolsó negyedére tehető. A gyermek meghatározatlan, kétértelmü mozgáshelyzete Lüszipposzt idézi, ahogyan testének arányai is.

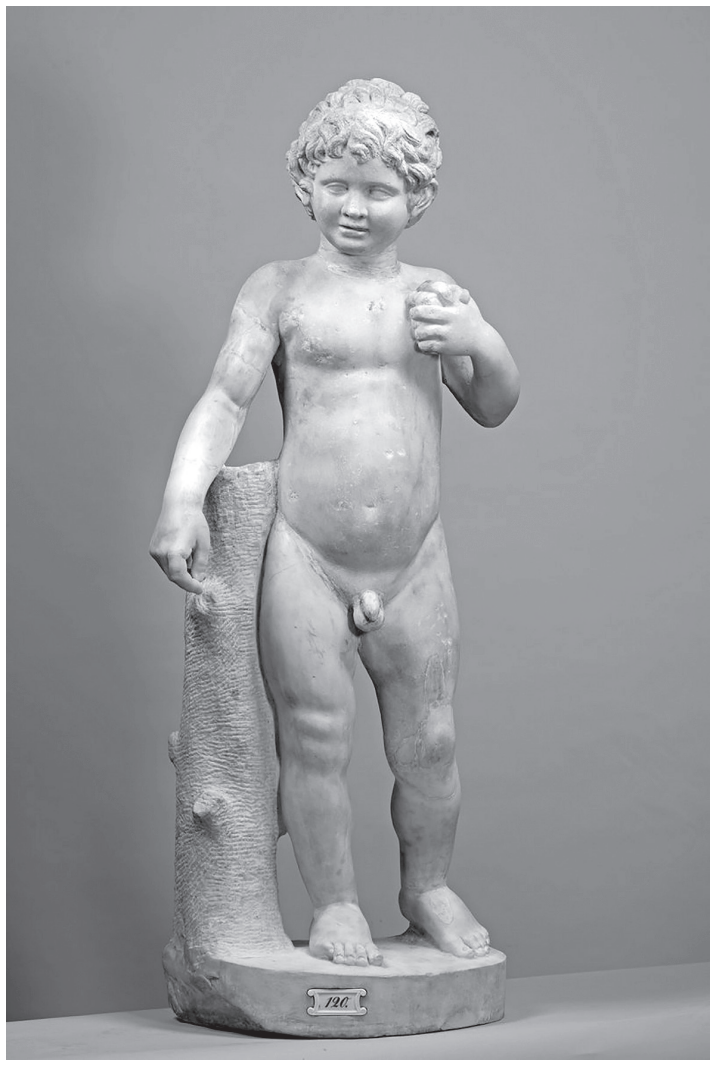

A kisfiú testével a jobb oldalánál elhelyezkedő fatörzshöz simul. Bár e mozzanat Praxitelész Hermészének fatörzshöz támaszkodását idézi, a gyermek itt ahelyett, hogy külső támasztékot keresne a térben, a fatörzs oldalához simul, ez pedig leginkább a gyermekkor természetközeli létállapotára utal. A művész a gyermeki psziché iránti fokozott érzékenységgel ábrázolja, amint a fiú játékosan végigtapogatja a fatörzs oldalát: így ismerkedik ő a természettel. Ugyanakkor a mű konkrét játéktevékenységre is utal, hiszen a mellkasához szorított

\footnotetext{
${ }^{58}$ A kép forráshelye: Szépművészeti Múzeum. https://www.szepmuveszeti.hu/mutargyak/kisfiuastragalosszal/ (2019. jún. 11.)
} 
asztragalosz (a juh vagy a kecske hátsó lábaiban található csigacsont) az ókori görögök kedvelt játéka volt, melyet kockajáték (csüdözés) céljából használtak (Rózsa-Szigeti 2018, 78-79).

A gyermek kissé pufók felsőteste, pufók arca, széles orra, sűrü, csigákba rendezett hajfürtjei gyermekded vonásokat jeleznek, felhíva a figyelmet a korabeli társadalomnak a gyermekkor sajátos vonásainak rögzítésére irányuló erőfeszítésére, mely pedig a gyermekhez fordulás társadalmi méretü mozzanatáról tanúskodik (Pukánszky 2004, 39; French 1998, 53-54; Fináczy 1922, 184). A fiú testhelyzete kissé bizonytalan, némi elmozdulást jelez a fatörzshöz képest, fejét oldalra biccenti, jelezve a gyermeki érdeklődés elevenségét, s egyúttal a pillanatszerűség benyomását kölcsönözve a szobornak. Végül a kisfiú gömbölyded testének formálhatónak tetsző végtagjai felidézik a görög nevelésfelfogás azon felfogását, mely szerint a gyermek testének alakíthatóságának analógiájára a gyermek egész lénye is formálható - ily módon, az anatómiai jegyek érzékletes kidolgozása révén hordozza magában e mü a nevelhetőség klasszikus, a hellenizmus korában is továbbélő eszméjét az abból fakadó tudatlanság és ártatlanság toposzával együtt (French 1998, 51).

\section{Összefoglalás}

A hellenizmus korának megnövekedett számú gyermekábrázolásai a gyermekkor anatómiai-fiziognómiai vonásainak naturális részletekben gazdag megjelenítését nyújtják, tanúskodva a kor gyermekség iránti fokozott érdeklődéséről. Az új korban a klasszikus korszak állandóságélménye által áthatott emberképével szemben a pillanatnyiság közegében mozgó ember természeti volta került előtérbe, így a javarészt érzéki vonatkozásainál fogva definiált gyermekkor ábrázolása is e korban prosperálhatott. Az írásunkban áttekintett gyermekéletképek azon túl, hogy a kor gyermekszemléletét közvetítik, magukban hordoznak bizonyos, a korszakra jellemző kulturális utalásokat, képesek megfogalmazni a kor egzisztenciális válságtól terhes hangulatát, időnként pedig rávilágítanak az új emberképet jellemző, olykor némi derütől sem mentes felszabadultságélményre is. A Spinario és a Gyermek lovas például mintha egy letünt történeti kor győzelemeszményének mondana búcsút, rávilágítva a kor individuumának gyötrelmeire és fájdalmaira, illetve a fájdalomtól való megszabadulás epikureus kívánalmára, a Libával birkózó kisfiú alakja - egy, a spirális kompozíciójánál fogva felmerülö markáns művészettörténeti analógia okán - pedig ironikus kulturális utalás a kor és a korábbi korok hősi eszményeire. Mindenesetre a kor gyermekábrázolásai nem pusztán a gyermekkorról szólnak, hiszen önmagukon túlmutatva képesek rávilágítani bizonyos korszakos jelentőségü, átfogó érvényü narratívákra is. 


\section{Irodalom}

Auboyer, Jeannine és munkatársai. 1986. A müvészet története: Az antik világ. Budapest: Corvina.

Bengtson, Hermann. 2009. A hellenisztikus világkultúra. Szeged: JATEPress.

Boardman, John. 2007. Görög müvészet. Budapest: Glória.

Castiglione László. 1968. Görög müvészet. Budapest: Corvina.

Castiglione László. 1996. Hellénisztikus müvészet. Budapest: Corvina.

Endrődy-Nagy Orsolya. 2015. A reneszánsz gyermekképe: A gyermekkép reneszánsza 14551517 között Európában. Ikonográfiai elemzés. Doktori disszertáció. Budapest: ELTE Eötvös Kiadó.

Falus Róbert. 2005. Az antik világ irodalmai. Budapest: Neumann Kht. http://mek.niif.hu/ 04700/04714/html/index.htm (2019. aug. 12.)

Fináczy Ernő. 1922. Az ókori nevelés története. Budapest: Hornyánszky Viktor.

Fox, Robin Lane. 1996. A hellenisztikus kultúra és irodalom. In Boardman, John-Griffin, Jasper-Oswyn, Murray: Az ókori görögök és rómaiak története. 355-382. Budapest: Maecenas.

French, Valerie. 1998. A gyermek hatásának története: ókori mediterrán civilizációk. In A gyermekkor története - szöveggyüjtemény, szerk. Vajda Zsuzsanna-Pukánszky Béla. 42-66. Budapest: Eötvös József Kiadó.

Hauser, Arnold. 1968. A müvészet és az irodalom társadalomtörténete. 1. Budapest: Gondolat.

Hegyi Dolores-Kertész István-Németh György-Sarkady János. 2002. Görög történelem a kezdetektöl Kr. e. 30-ig. Budapest: Osiris.

Hoffmann Zsuzsanna. 2009. Antik nevelés. Veszprém: Iskolakultúra.

Long, Anthony Arthur-Sedley, David N. 2014. A hellenisztikus filozófusok. Budapest: Akadémiai Kiadó.

Németh András. 2004. Az ember - és „világának” változásai. In Németh András-Pukánszky Béla. A pedagógia problématörténete. 11-98. Budapest: Gondolat.

Panofsky, Erwin. 1998. Idea: Adalékok a régebbi müvészetelmélet fogalomtörténetéhez. Budapest: Corvina.

Pukánszky Béla. 2004. Fejezetek a gyermekkor és a családi nevelés történetéből. In Németh András-Pukánszky Béla. A pedagógia problématörténete. 259-330. Budapest: Gondolat.

Rózsa Zoltán-Szigeti Judit. 2018. A pénz nem játék, vagy mégis? Határtalan régészet 3 (1): 78-80. http://epa.oszk.hu/03200/03255/00005/pdf/EPA03255_hatartalan_regeszet_ 2018_1_078-080.pdf (2019. jún. 11.)

Sarti, Susanna. 2007. Görög müvészet. Budapest: Corvina.

Siebler, Michael. 2008. Görög müvészet. Budapest: Vince.

Swiderkowna, Anna. 1981. A hellenizmus kultúrája. Budapest: Gondolat.

Tatarkiewicz, Władisław. 2006. Az esztétika alapfogalmai. Budapest: Kossuth Kiadó. https:// www.tankonyvtar.hu/hu/tartalom/tamop425/2011_0001_654_tatarkiewicz/adatok. html (2019. jún. 28.) 
Támba Renátó. 2017. Gyermekkor a vásznakon: A dualizmuskori gyermekszemlélet az alföldi iskola festészetében. Budapest: Storming Brain.

The British Museum. (é. n. a). The Spinario. The British Museum. https://www.britishmuseum. org/research/collection_online/collection_object_details.aspx?objectId=460414\&partI $\mathrm{d}=1$ \&object $=20170 \&$ sortBy=imageName\&page $=1$ (2019. jún. 11.)

The British Museum. (é. n. b). Figure. The British Museum. https://www.britishmuseum. org/research/collection_online/collection_object_details.aspx?assetId=363208001\&o bjectId=460450\&partId=1 (2019. jún. 11.)

Zamarovsky, Vojtech. 1980. A görög csoda. Budapest: Madách.

Renato TAMBA

\section{PREDSTAVLJANJE DECE U HELENISTIČKOJ GRČKOJ SKULPTURI}

U ovom radu nastojim da pružim presek predstavljanja dece u helenističkom grčkom vajarstvu, s namerom da pomoću metodoloških sredstava ikonografije u istoriografiji detinjstva ukažem na idejne i društvenoistorijske motive koji izražavaju tada nastajuću sliku o čoveku i provlače se kroz umetnička dela, kao i na specifične obrasce poimanja deteta koji se očitavaju u delima. Tokom istraživanja jednako su uzeti u obzir idejni, društvenoistorijski, umetnički i aspekti istoriografije detinjstva, stoga je pre svega bilo neophodno odrediti istorijske okvire relevantne za temu ovog rada. Cilj istraživanja je da pruži sveobuhvatnu sliku o predstavljanju deteta u datoj epohi, da istovremeno osvetli ikonografska i ikonološka značenja koja se očitavaju delima, zatim da ukaže na idejna značenja skrivena u delima kao i na kulturne reference, budući da ova dela nadilazeći tematiku detinjstva reflektuju pitanja tadašnjeg vremena otvorenog ka egzistencijalnim pitanjima, i u krajnjoj liniji prate put etičkog relativizma.

Ključne reči: helenizam, poimanje deteta, individualističko-naturalističko predstavljanje, spinario, efebos

\section{Renátó TÁMBA}

\section{REPRESENTATIONS OF CHILDREN IN THE HELLENISTIC GREEK SCULPTURE}

In this paper, I attempt to provide a cross-section of the representations of children in Hellenistic Greek sculpture with the aim of pointing out ideological and socio-historical motives through the methodological means of iconography in the historiography of childhood that express the then-emerging image of man, and flow through works of art, as well as specific patterns of understanding of the child that are noticeable in those artworks. During the research, ideological, socio-historical, artistic and aspects of childhood historiography were equally taken into account, therefore it was first and foremost necessary to determine the historical frameworks relevant to the topic of this paper. The aim of the research is to 
provide a comprehensive picture of the representation of the child in the given era, at the same time pointing at the iconographic and iconological meanings seen in the works, then to point out the ideological meanings hidden in the works as well as the cultural references, since these works go beyond the subject of childhood to reflect questions of the time open to existential issues, and ultimately follow the path of ethical relativism.

Keywords: hellenism, understanding of the child, individualistic-naturalistic representation, spinario, ephebos 